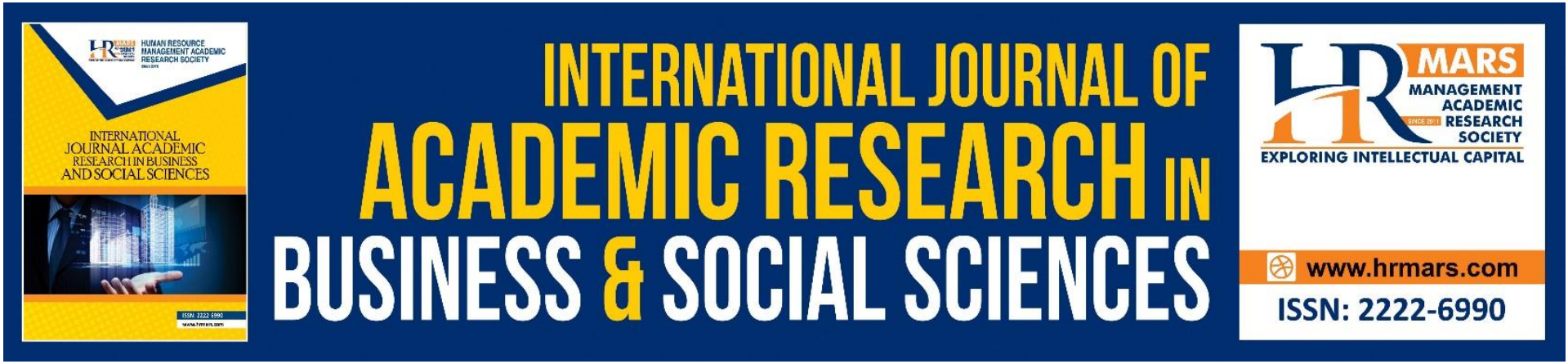

\title{
Corporate Governance and Culture: A Systematic Review
}

\section{Afkar Majeed, Rohaida Basiruddin, Ruaa Binsaddig}

To Link this Article: http://dx.doi.org/10.6007/IJARBSS/v11-i11/11338

DOI:10.6007/IJARBSS/v11-i11/11338

Received: 12 September 2021, Revised: 07 October 2021, Accepted: 24 October 2021

Published Online: 08 November 2021

In-Text Citation: (Majeed et al., 2021)

To Cite this Article: Majeed, A., Basiruddin, R., \& Binsaddig, R. (2021). Corporate Governance and Culture: A Systematic Review. International Journal of Academic Research in Business and Social Sciences, 11(11), 789 $-799$.

\section{Copyright: (c) 2021 The Author(s)}

Published by Human Resource Management Academic Research Society (www.hrmars.com)

This article is published under the Creative Commons Attribution (CC BY 4.0) license. Anyone may reproduce, distribute, translate and create derivative works of this article (for both commercial and non-commercial purposes), subject to full attribution to the original publication and authors. The full terms of this license may be seen at: http://creativecommons.org/licences/by/4.0/legalcode

Vol. 11, No. 11, 2021, Pg. $789-799$

Full Terms \& Conditions of access and use can be found at http://hrmars.com/index.php/pages/detail/publication-ethics 


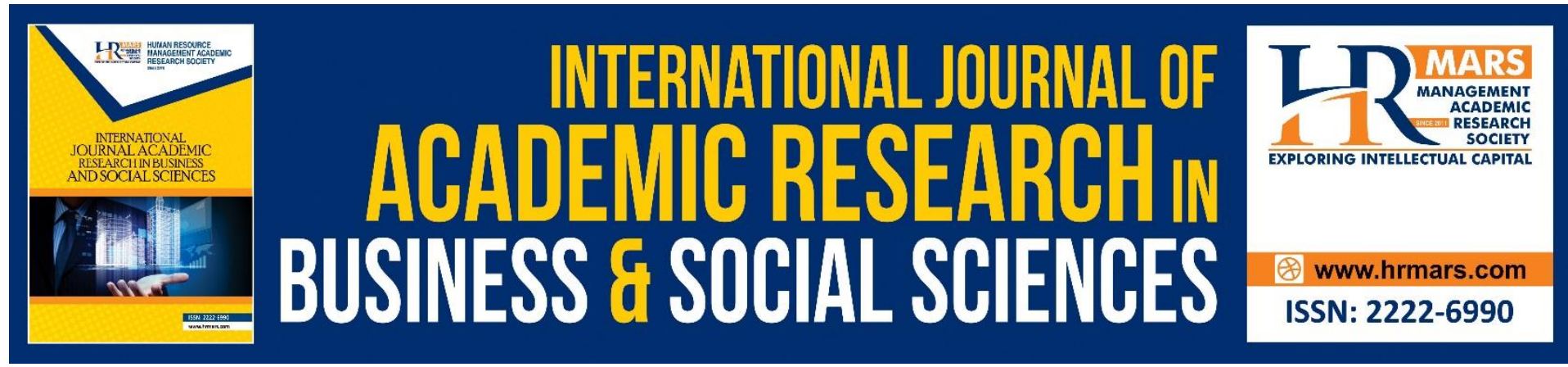

\title{
Corporate Governance and Culture: A Systematic Review
}

\author{
${ }^{1}$ Afkar Majeed, ${ }^{2}$ Rohaida Basiruddin, ${ }^{3}$ Ruaa Binsaddig \\ ${ }^{1,2}$ Azman Hashim International Business School Universiti Teknologi Malaysia Kuala Lumpur, \\ ${ }^{3}$ College of Business Administration, University of Business and Technology, Jeddah, Saudi \\ Arabia \\ 1Email: afkarmajeedbhatti@gmail.com
}

\begin{abstract}
The primary aim of this paper is to provide a systematic review of literature on corporate governance and cultural diversity. The systematic review is conducted using qualitative and quantitative articles published in Scopus and web of science. This study is being undertaken in the recent period, i.e., 2016 to 2020. The initial sample comprised 247 papers from Scopus and web and science. After the screening, the sample thus obtained includes 45 studies for the analysis. The result highlights that the cultural diversity of the board is an essential component for improving governance. The fruits of cultural diversity can be obtained in multiple ways; therefore, management of the company and the managers need to be particularly careful while diversifying their corporate boards. Furthermore, the results show that culture is equally important for developed, developing, and emerging economies.
\end{abstract}

Keywords: Systematic Review, Corporate Governance, Cultural Diversity

\section{Introduction}

Corporate governance has evolved after major world scandals like Enron, Tyco, and WorldCom, etc. The literature mainly focused on audit committees and boards, financial reporting quality, corporate social responsibility, etc. The majority of the literature has analyzed corporate governance practices on firm performance (FP). The best governance practices positively impact FP, whereas inferior governance practices negatively impact FP. Literature shows that developed countries have superior governance mechanisms as compared to developing and emerging countries. It is also observed that developed countries have less concentrated ownership structures, making the emergence of agency problems minimal and disclosure maximum. Whereas, in developing countries, primarily ownership concentration is high, which induces information asymmetries among stakeholders; as a result, agency conflict rises, which deteriorates FP.

A wide array of literature has discussed corporate governance concerning board size, board independence, board meetings, gender diversity of the board, chairman CEO duality, audit committee $(A C)$ independence, audit $A C$ size, $A C$ meetings, financial expertise of $A C$, skill, and experience of $A C$, quality financial reporting and corporate social responsibility. In the recent literature, a visible shift is being observed. Several studies have highlighted that 
the invisible board diversity plays an influential role in shaping corporate governance practices that ultimately affect the FP.

The invisible type of board diversity is the cultural diversity that is generally being neglected. Therefore, recent studies have measured cultural diversity with colour, religion, and language, which only measures one aspect of culture. Culture is a multidimensional and broader concept. Reshaping of corporate governance practices is mainly due to globalization in board rooms. Literature highlights that board rooms are more culturally diverse at present as compared to the past (Park and Zhang, 2020; Ntongho, 2016). Bindabel (2020) states that a culturally diverse board is more dynamic. Therefore there are more chances of innovation and creativity which will have a positive effect on firm performance. Mirza et al (2020) board diversity attract more investment opportunities. Wang et al (2020) explain that individual board members process-specific unique characteristics because of past belongings that cannot be easily changed, affecting FP. Griffin et al (2017) explain that individuals' cultural and managerial values vary across firms that affect FP differently. Hence it can be inferred that specific cultural values, norms, and beliefs can benefit one company, whereas similar results cannot be achieved in different settings. Individuals who belong to different cultures will behave differently because of unique norms and values, i.e., an individual from an individualistic culture will behave differently compared to an individual from a collectivistic culture. The same goes for masculinity, uncertainty avoidance, and power distance.

- The main objective of this study is to provide a systematic review of literature that discusses how cultural diversity of board effect corporate governance practices and FP.

The rest of the paper is organized in the following pattern: Second part explains the research methodology that is being used in this study. Whereas, section 3 illustrates the results of the investigation. How different results are extracted. Part 4 of this paper explains the conclusion, ghted limitations, and study implications.

\section{Methodology}

The methodology of this paper revolves around the systematic review process. A number of previous studies are using this method. Ahmad and Omar (2016); Almaqtari et al (2020). The systematic review follows a transparent and scientific process; this method doesn't use any statistical analysis tools. The search strategy is based upon PRISMA philosophy. In this study, two search terms are used, i.e., "Corporate governance" and "Culture diversity." The period that is selected for the study is from 2016 to 2020. Therefore results show recent research trends.

Additionally, the selected study characteristics were qualitative and quantitative. The current study has selected the two most prestigious databases, i.e., Scopus and web of science. Furthermore, those studies were included that are related to corporate governance and cultural diversity. All the selected literature is written and reported in English, and no other language paper is selected for review. Moreover, no conference paper and no book chapter is being included in the final sample.

\section{Results}

Figure 1 explains the search results from Scopus and web of science from 2016 -2020. Initially, 206 papers were selected from Scopus and 41 from the web of science. Thus, the total number of papers that cleared initial screening was $n=247$. After the initial assessment, 30 more articles were removed because of duplication. Eighty papers were dropped after 
reviewing the title and abstract. At the same time, 110 papers were excluded after full-text assessment. Lastly, the final sample of the study consists of 45 articles.

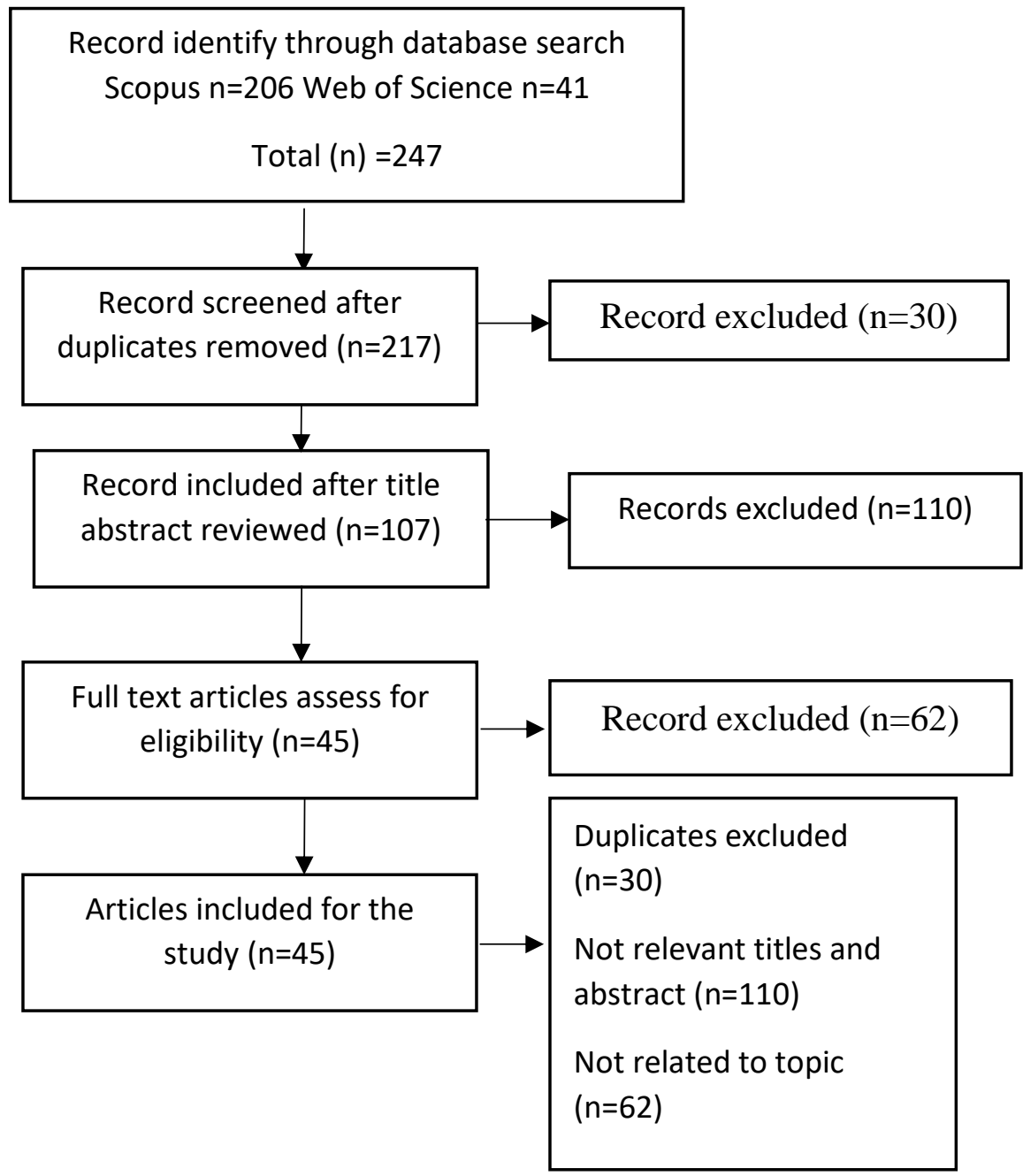

Figure.1 Literature flow

Figure 2 represents the type of method that is being used by the selected sample. The studies can be divided into two significant domains, i.e., qualitative and quantitative. Results indicated that the majority of studies follow the quantitative methodology. The percentage of quantitative studies in the sample is $87 \%$. In contrast, $13 \%$ of the studies follow the qualitative methods. 


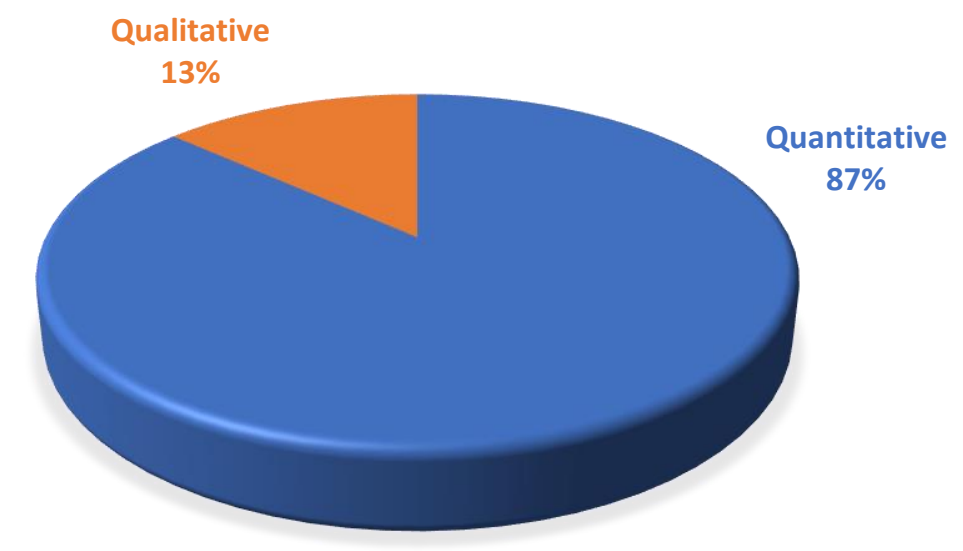

FIGURE 2:RESEARCH STUDY METHOD

Figure 3 shows the number of countries where these studies are being published. The graphical line indicates that the highest number of selected studies are not from a single country. Therefore. It can be inferred that culture is multi-country and broad subject. From the below figure, it can be concluded that a large number of studies were conducted on developed and developing economies, particularly China, the USA, the Uk, Malaysia, India, and Pakistan, which is also evidence of its importance.

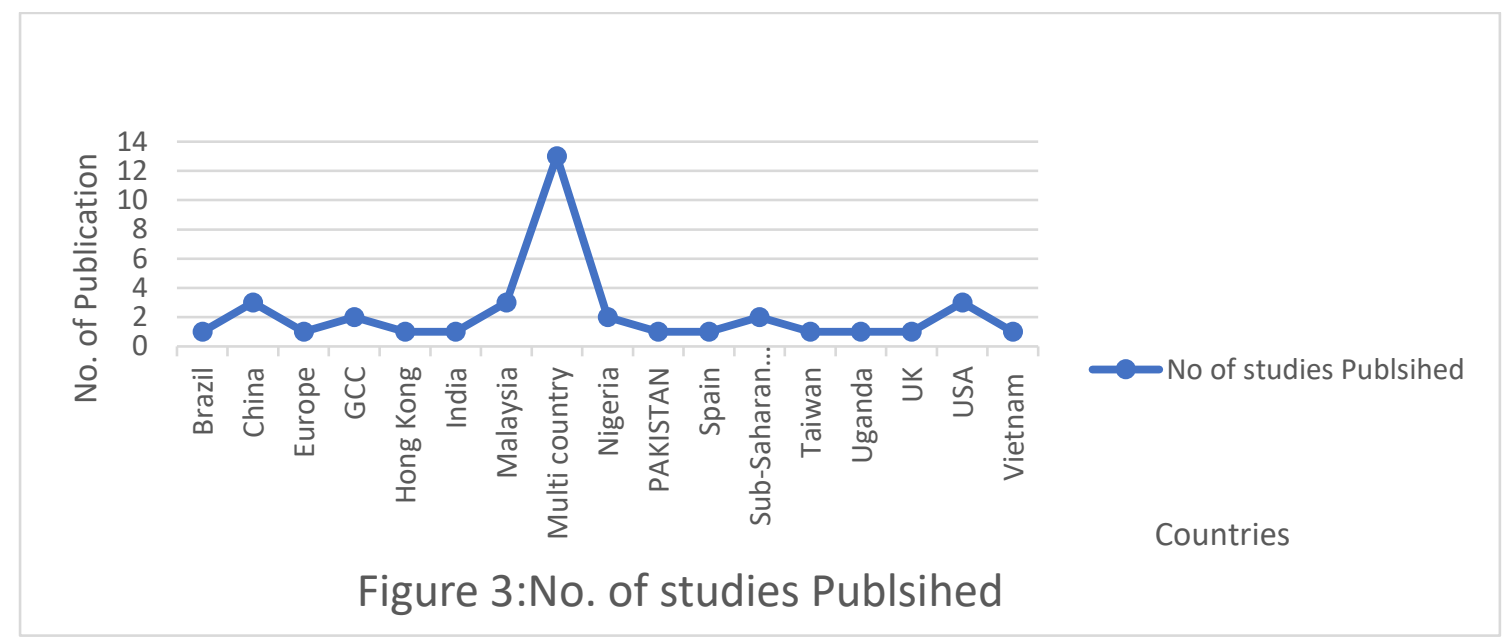

Citation is another critical factor that highlights the importance of cultural diversity. Figure 4 shows the cite scores of the entire sample from 2016-2020. The graphical representation shows that literature is growing in this field. The vast majority of scholars are researching the various topic of corporate governance by using multiple aspects of culture. 


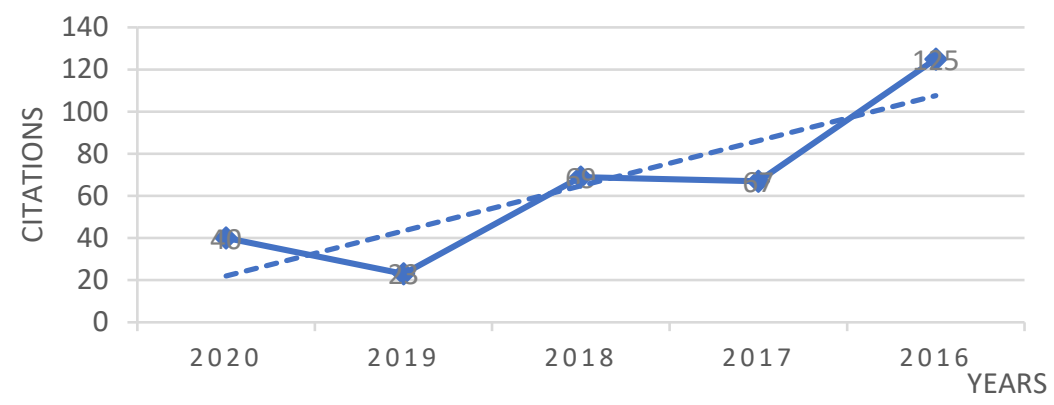

FIGURE NO.4:CITATIONS PER YEAR

Synthesis Table: 1

\section{Authors \\ Title}

Ali and (2016)

Azmi

Gyapong et al., Do Women and Ethnic Minority Directors (2016)

Ntongho (2016)

Duong

al.,(2016)

Kim and Danie

(2020)

Nurunnabi

(2017)

(2017)

Griffin

al.,(2017)

Humphries and Whelan (2017)

Osemeke and The effect of culture on corporate Osemeke (2017) governance practices in Nigeria

Nalukenge et Corporate governance, ethics, internal al.,[26]

Del Brio et al., How does interpersonal justice affect (2018) controls and compliance with IFRS

\section{Apartheid South Africa}

Culture and corporate governance convergence

et National culture and corporate governance

Religion and Corporate
Evidence from 32 Countries

Does cultural value affect board efficacy? Insights on international corporate governance governance

et National culture: The missing country-level determinant of corporate governance

National culture and corporate governance codes outside directors' governance behavior? A cross-cultural comparison

\section{Findings}

Muslim board members contribute positively towards performance.

$C D$ adds more value to the board, which results in better performance.

Culture shapes governance mechanisms.

Culture invisibly affects governance choices.

The religious diversity of the board affects governance practices.

Religious diversity on the corporate board decreases board efficiency.

Individualistic cultures follow superior governance practices.

The effect of cultures varies across the firms because of different firm needs and managerial capabilities.

$C D$ is vital for companies while considering expansion.

Culture can transform power, procedures, and policymaking.

Ethical culture contributes positively towards quality reporting.

Board of directors of different origins reacts according to their cultural values. 

Griffin
al.,(2017)
et National Culture and the Value Implication of Corporate Governance

Rafinda et al., Board diversity, risk and sustainability of (2018)

Nakpodia and Corporate governance and elites Adegbite (2018)

Dolfsma and The emergence and performance of the McCarthy

(2018)

Lopez-

Quesadaet

al.,(2018)

Li et al., (2018)

Demographic diversity on boards and employer/employee relationship

Nasir et al., Corporate governance, board ethnicity and (2019) financial statement fraud: evidence from Malaysia

Jiang et al., Chairperson collectivism and the (2019)

\section{Boateng}

al.,(2020)

Yeung $(20180$ compensation gap between managers and employees: Evidence from China

et National culture, corporate governance and corruption: A cross-country analysis

Nonlinear Effect of Board Size on Corporate Performance: Impact of the Cultural Backgrounds of Directors in Hong Kong

Khan et al., The mediating role of innovation between (2019) corporate governance and organizational performance: Moderating role of innovative culture in Pakistan textile sector

Al-Qahtani and The effect of board diversity on disclosure Elgharbawy

(2020)

Mirza

al.,(2020) and management of greenhouse gas information: evidence from the United Kingdom

et The value of board diversity in the relationship of corporate governance and investment decisions of pakistani firms

Park and Zhang Cultural entrepreneurship in corporate (2020) governance practice diffusion: Framing of "independent directors" by U.S.-Listed Chinese companies

Different cultural dimensions affect differently, i.e., individualism is positively related, whereas uncertainty avoidance has negatively related.

$C D$ is the tool of better governance, particularly in emerging markets.

Different political, cultural, and religious shape various governance policies.

Cultural distance is negatively associated with firm performance.

Better governance culture had a positive impact on performance.

$C D$ improves human resource development.

Foreign independent directors reduce fraud or misrepresentation of financial statements.

Collectivistic culture chairperson has longer tenures as compare to individualistic chairpersons.

Culture dimensions moderates between CG and level of corruption.

$C D$ improves firm performance.

Innovative culture enhances firm performance.

Board diversity encourages information disclosure.

Diversity has a positive impact on investment decisions.

Cultural diversity (CD) effects governance practices as well as selection of resources. 
Bindabel (2020) M\&a open innovation, and its obstacle: A CD boosts innovation and creativity. case study on GCC region

Wang et al., Confucianism and Firm Performance

(2020)

Lobrij et al., What national governance codes say about

(2020) corporate culture

Arnaboldi et al., (2020)

Tran

al.,(2020)

Ismail (2020)

Ortas and

Gallego-Álvarez

(2020)

Fernández-

Temprano and

Tejerina-Gaite

(2020) heterogeneity: what works for EU banks?

et Corporate governance in the largest family firms in Latin America

The impact of board characteristics on cooperative reputation from the lense of resource-based view theory (RBVT) responsibility performance and tax aggressiveness: The moderating role of national culture Types of director, board diversity and firm performance
CD improves managerial efficiency.

Culture influence on national governance codes.

Bank performance not affected by CD.

Ownership structure influences board and management.

CD improves managerial efficiency.

Cultural dimensions effects firm social performance.

Multinational boards is positively related to firm performance.

The above table shows the findings and trends of previous literature. The previous literature has used religion as a proxy of culture. But religion is not considered as a comprehensive proxy as a substitute for culture. However, certain religions possess particular social norms and attribute different from other religions, which ultimately shape human behaviour, and their impact can be observed in performance (Ali and Azmi, 2016; Nurunnabi, 2017; Kim and Daniel, 2016).

The second aspect of the cultural diversity that is extracted from the systematic analysis of literature is that cultural diversity of board has a multi-facet effect on the firm performance, i.e., when companies are expanding internationally, the CD plays a positive and significant role. Humphries and Whelan (2017). Likewise, Li et al (2018) highlighted that the diversity of board improves human resource development; therefore, better governance practices are adopted by the companies that contribute positively to firm performance. Moreover, Khan et al (2019) established that mixing different cultures enhances innovation and creativity. Mirza et al (2020) suggested that board diversity is an essential factor while making investment decisions. Wang et al (2020) highlighted that cultural diversity improves managerial efficiency. Therefore, it is concluded that the cultural diversity of the board is a crucial factor that can have a multidimensional effect on the working of the corporate board, which impacts the firm performance directly or indirectly.

Thirdly, after the analysis, it is inferred that culture transforms various governance practices, policies, procedures, and choices (Ntongho, 2016; Osemeke \& Osemeke, 2017; Yeung, 2018), their effect can be seen in the firm performance. Other than culture, literature also highlighted that various cultural dimensions like individualism, power distance, uncertainty avoidance, and masculinity also affect governance and performance choices; 
moreover, the literature shows that dimensions like individualism contribute positively, whereas masculinity and uncertainty avoidance have a negative impact. (Feng et al., 2017; Griffin et al., 2017; Dolfsma and McCarthy, 2018; Jiang et al., 2019).

The literature also highlighted that the cultural diversity of the board is more beneficial for emerging and developing economies than developed economies. Furthermore, $C D$ of the board also brings foreign skill, experience, network, and independence that improves the governance structure in emerging and developing economies, minimizing agency conflict, particularly in high ownership concentrated firms (Tran et al., 2020; Park and Zhang, 2020; Rafinda et al., 2018).

\section{Conclusions}

This paper aims to provide a systematic literature review on how the cultural diversity of boards affects corporate governance practices and firm performance. The study has selected the two most central databases for choosing the sample, i.e., Scopus and web of science. The final sample comprises of 45 studies from both databases. The selected studies were from 16 different countries. Moreover, out of 45 total studies, 13 were conducted in multiple countries, showing that cultural diversity is a broader and global subject. The investigation based upon our selected sample suggests that the culture is an invisible mechanism that affects various governance choices of board members like the selection of different investment opportunities, information dissemination to other stakeholders, financial reporting mechanisms, etc. Therefore, managers and the company's management must consider culture as an essential factor while making certain decisions. The study has some limitations as well. First, the study only uses two such terms, i.e., corporate governance and cultural diversity. Secondly, only two databases are used, i.e., Scopus and web of science. Thirdly, the study only considers those journal articles that are published in the English language. Fourthly, the study only considers the recent five years. In future studies which conducting systematic analysis, other such terms like dimensions of the cultures, namely, individualism, masculinity, uncertainty avoidance, and power distance, can be used to obtain more specific results. In future studies, other databases can be used. Furthermore, future studies can be conducted on more significant periods to capture a better picture.

This study contributes to the existing literature in many ways. First, the growing literature on various aspects of culture is evidence of its importance. Second, the study highlights the importance of cultural diversity, which is the under-searched domain. Third, The study snapshot the most recent evidence from existing literature. Another contribution of this study is that the study highlights the various aspects of culture that affect firm performance. Additionally, cultural diversity is a double edged sword, as highlighted in the literature. Therefore, this study is an addition to the current debate. Finally, corporate boards are becoming globalized, which have a direct effect on various aspects of performance. Therefore, this study investigated how different cultures in board rooms can be advantageous or challenging for optimizing firm performance.

\section{References}

Ahmad, S., \& Omar, R. (2016), "Basic corporate governance models: a systematic review", International Journal of Law and Management, Vol. 58 No. 1, pp. 73-107.

Ali, M., \& Azmi, W. (2016). Religion in the boardroom and its impact on Islamic banks' performance. Review of Financial Economics, 31, 83-88. 
Almaqtari, F. A., Al-Hattami, H. M., Al-Nuzaili, K. M., \& Al-Bukhrani, M. A. (2020). Corporate governance in India: A systematic review and synthesis for future research. Cogent Business \& Management, 7(1), 1803579.

Al-Qahtani, M., \& Elgharbawy, A. (2020). The effect of board diversity on disclosure and management of greenhouse gas information: evidence from the United Kingdom. Journal of Enterprise Information Management.

Arnaboldi, F., Casu, B., Kalotychou, E., \& Sarkisyan, A. (2020). The performance effects of board heterogeneity: what works for EU banks?. The European Journal of Finance, 26(10), 897-924.

Bindabel, W. (2020). M\&A Open Innovation, and Its Obstacle: A Case Study on GCC Region. Journal of Open Innovation: Technology, Market, and Complexity, 6(4), 138.

Boateng, A., Wang, Y., Ntim, C., \& Glaister, K. W. (2020). National culture, corporate governance and corruption: A cross-country analysis. International Journal of Finance \& Economics.

Del Brio, E. B., Hernández-Maestro, R. M., \& Yoshikawa, T. (2018). How does interpersonal justice affect outside directors' governance behavior? A cross-cultural comparison. Review of Managerial Science, 12(3), 683-709.

Dolfsma, W., \& McCarthy, K. (2018). The emergence and performance of the Chinese merger market and the impact of partner location. Journal of Chinese Economic and Business Studies, 16(1), 39-58.

Duong, H. K., Kang, H., \& Salter, S. B. (2016). National culture and corporate governance. Journal of International Accounting Research, 15(3), 67-96.

Feng, M., Kang, T., \& Nabar, S. (2017). National societal values and corporate governance. International Journal of Emerging Markets.

Fernández-Temprano, M. A., \& Tejerina-Gaite, F. (2020). Types of director, board diversity and firm performance. Corporate Governance: The International Journal of Business in Society.

Griffin, D. W., Guedhami, O., Kwok, C. C., Li, K., \& Shao, L. (2017). National culture and the value implication of corporate governance. Available at SSRN 2400078.

Griffin, D., Guedhami, O., Kwok, C. C., Li, K., \& Shao, L. (2017). National culture: The missing country-level determinant of corporate governance. Journal of International Business Studies, 48(6), 740-762.

Gyapong, E., Monem, R. M., \& Hu, F. (2016). Do women and ethnic minority directors influence firm value? Evidence from post-apartheid South Africa. Journal of Business Finance \& Accounting, 43(3-4), 370-413.

Humphries, S. A., \& Whelan, C. (2017). National culture and corporate governance codes. Corporate Governance: The International Journal of Business in Society.

Ismail, A. M., Ahmadi, S. M., Yatim, N., \& Ismail, P. M. (2020). The impact of board characteristics on co-operative reputation from the lense of resource-based view theory (RBVT). International Journal of Financial Research, 11(3), 43-61.

Jiang, W., Lin, B., Liu, Y., \& Xu, Y. (2019). Chairperson collectivism and the compensation gap between managers and employees: Evidence from China. Corporate Governance: An International Review, 27(4), 261-282.

Khan, S. N., Hussain, R. I., Maqbool, M. Q., Ali, E. I. E., \& Numan, M. (2019). The mediating role of innovation between corporate governance and organizational performance: Moderating role of innovative culture in Pakistan textile sector. Cogent Business \& Management. 
Kim, J., \& Daniel, S. J. (2016). Religion and corporate governance: Evidence from 32 countries. Asia-Pacific Journal of Financial Studies, 45(2), 281-308.

Li, J., Zhang, Y., Chen, S., Jiang, W., Wen, S., \& Hu, Y. (2018). Demographic diversity on boards and employer/employee relationship. Employee Relations.

Lobrij, M. F., Kaptein, M., \& Lückerath-Rovers, M. (2020). What national governance codes say about corporate culture. Corporate Governance: The International Journal of Business in Society.

López-Quesada, E., \& Idowu, S. O. (2018). Corporate governance practices and comprehensive income. Corporate Governance: The international journal of business in society.

Mirza, N. I., Malik, Q. A., \& Mahmood, C. K. (2020). The value of board diversity in the relationship of corporate governance and investment decisions of pakistani firms. Journal of Open Innovation: Technology, Market, and Complexity, 6(4), 146.

Nakpodia, F., \& Adegbite, E. (2018). Corporate governance and elites. In Accounting Forum, Vol. 42, No. 1, pp. 17-31

Nalukenge, I., Nkundabanyanga, S. K., \& Ntayi, J. M. (2018). Corporate governance, ethics, internal controls and compliance with IFRS. Journal of Financial Reporting and Accounting.

Nasir, N. A. B. M., Ali, M. J., \& Ahmed, K. (2019). Corporate governance, board ethnicity and financial statement fraud: evidence from Malaysia. Accounting Research Journal.

Ntongho, R. A. (2016). Culture and corporate governance convergence. International Journal of Law and Management.

Nurunnabi, M. (2017). Does cultural value affect board efficacy? Insights on international corporate governance. International Journal of Law and Management.

Ortas, E., \& Gallego-Álvarez, I. (2020). Bridging the gap between corporate social responsibility performance and tax aggressiveness. Accounting, Auditing \& Accountability Journal.

Osemeke, N., \& Osemeke, L. (2017). The effect of culture on corporate governance practices in Nigeria. International Journal of Disclosure and Governance, 14(4), 318-340.

Park, S. H., \& Zhang, Y. (2020). Cultural entrepreneurship in corporate governance practice diffusion: framing of "independent directors" by US-listed chinese companies. Organization Science, 31(6), 1359-1384.

Rafinda, A., Rafinda, A., Witiastuti, R. S., Suroso, A., \& Trinugroho, I. (2018). BOARD DIVERSITY, RISK AND SUSTAINABILITY OF BANK PERFORMANCE: EVIDENCE FROM INDIA. Journal of Security \& Sustainability Issues, 7(4).

Vazquez, P., Carrera, A., \& Cornejo, M. (2020). Corporate governance in the largest family firms in Latin America. Cross Cultural \& Strategic Management.

Wang, L., Zhang, Y., Wang, L., \& Fu, J. (2020). Confucianism and Firm Performance. Front. Phys. 8: 319. doi: 10.3389/fphy.

Yeung, J. C. (2018). Nonlinear effect of board size on corporate performance: impact of the cultural backgrounds of directors in Hong Kong. Asia-Pacific Journal of Financial Studies, 47(1), 107-131. 